\title{
Influence of environmental and spatial factors on the distribution of surface sediment diatoms in Chaohu Lake, southeast China
}

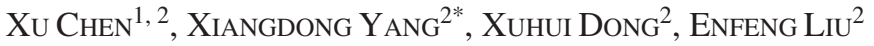 \\ ${ }^{1}$ Department of Geography, Faculty of Earth Sciences, China University of \\ Geosciences, Wuhan 430074, People's Republic of China \\ ${ }^{2}$ State Key Laboratory of Lake Science and Environment, Nanjing Institute of \\ Geography and Limnology, Chinese Academy of Sciences, Nanjing 210008, \\ People's Republic of China
}

\begin{abstract}
The spatial distribution of surface sediment diatoms in Chaohu Lake (southeast China), and their relationships with environmental and spatial variables were analyzed in this study. The diatom assemblages were dominated by planktonic species. Three dominant species Cyclostephanos dubius, Aulacoseira granulata and Aulacoseira alpigena are unevenly distributed across the lake. The distribution of surface sediment diatoms must be subject to trophic status, hydrodynamics and other spatial variables in the lake.
\end{abstract}

Keywords: Aulacoseira, Cyclostephanos, diatom, sediment, distribution, Chaohu Lake

Abbreviations: $\chi_{\mathbf{f d}}-$ the percentage frequency dependent susceptibility, LOI - loss on ignition, FPF - fine particle fraction, $\mathbf{M D}$ - median grain size, $\mathbf{P C N M}$ - principal coordinates of neighbour matrices

\section{Introduction}

The spatial structure of biological populations and communities plays a central role in many ecological theories, such as the theories of succession, adaptation, competition and so on (LEGENDRE and FORTIN 1989). In order to untangle the spatial patterns and include space as an explicit variable in ecological modeling, many methods have been proposed during the recent years, such as the geographic coordinate method, trend-surface analysis and principal coordinates of neighbour matrices (PCNM) analysis (cf. BORCARD et al. 2004). Among these methods, PCNM analysis can achieve a spectral decomposition of the spatial relationships among the sampling sites (BORCARD and LEGENDRE 2002). And

* Corresponding author, e-mail: xdyang@niglas.ac.cn

Copyright $^{\circledR} 2012$ by Acta Botanica Croatica, the Faculty of Science, University of Zagreb. All rights reserved. 
PCNM analysis can be easily incorporated into canonical analysis models, providing a useful tool to assess the influence of spatial structure (DRAY et al. 2006). For instance, recent studies argued that the spatial factor had an important effect on the distribution of fish in lakes based on PCNM analysis (BRIND'AMOUR et al. 2005, SHARMA et al. 2011). The spatial patterns of not only large organisms but also of various microorganisms (e.g., phytoplankton, cladoceran and chironomid) have attracted much attention recently (BEISNER et al. 2006, SweETMAn et al. 2010, CAO et al. 2012).

Diatoms are unicellular and eukaryotic organisms, occurring throughout the world, growing in almost all aquatic environments (BATTARBEE et al. 2001). The relationships between diatoms and environmental variables act a vital role in limnological and paleolimnological researches (SMOL and CUMMING 2000). Most studies ignore the effect of spatial variables on diatom distribution. However, YANG et al. (2009) indicated that spatial variables were a further influence on diatom distribution in the Round Loch of Glenhead, a small lake in south-west Scotland. Unlike small lakes, large lakes always exhibit complex spatial gradients (NöGES et al. 2008, CóZAR et al. 2012). It is assumed that spatial factors should impose an important role in diatom distribution in large lakes.

In this study, we consider the importance of environmental and spatial factors on diatom distribution in Chaohu Lake, a large $\left(770 \mathrm{~km}^{2}\right)$ shallow lake in southeast China. Diatoms and sedimentary proxies from surface sediments were analyzed in the laboratory. Meanwhile, spatial factors were calculated using PCNM analysis. Thereafter, we estimated the effects of spatial and environmental variables on surface sediment diatoms quantitatively, using the canonical analysis model.

\section{Materials and methods}

\section{Study site}

Chaohu Lake (N $31^{\circ} 25^{\prime}-31^{\circ} 43^{\prime}$, E $\left.117^{\circ} 17^{\prime}-117^{\circ} 51^{\prime}\right)$ is the fifth largest freshwater lake located in the Yangtze floodplain of southeast China (Fig. 1). The Chaohu watershed is located in a subtropical monsoon climate zone with an annual average temperature of ca. $16.1^{\circ} \mathrm{C}$, an annual average rainfall of ca. $996 \mathrm{~mm}$ and an annual mean wind speed of ca. 4.1 $\mathrm{m} \mathrm{s}^{-1}$ (WANG and Dou 1998). The lake has an open water area of $770 \mathrm{~km}^{2}$ with a mean water depth of $3.0 \mathrm{~m}$. Between 1984 and 2006, the average concentrations of total phosphorus (TP), total nitrogen (TN) and chlorophyll a (Chl a) were $256 \mu \mathrm{g} \mathrm{L}^{-1}, 2850 \mu \mathrm{g} \mathrm{L}^{-1}$ and $20-40$ $\mu \mathrm{g} \mathrm{L}^{-1}$ respectively (XIE 2009). The main sources of nutrients come from the inputs of the rivers located in the western region, including Nanfei River and Paihe River (Fig.1) (Shang and Shang 2005). Due to the increasing nitrogen and phosphorus inputs from industrial wastewater, domestic sewage and agricultural fertilizers since the late 1970s, the lake has suffered serious eutrophication in the past several decades.

\section{Sampling and laboratory analyses}

Thirty nine surface sediment samples were collected in June 2009 using a Kajak gravity corer. The top $1 \mathrm{~cm}$ sediment was removed for surface sediment samples. All samples were transported back to the laboratory and stored at $4{ }^{\circ} \mathrm{C}$. Sedimentary proxies were analyzed in the State Key Laboratory of Lake Science and Environment, including particle size, magnetic susceptibility, loss on ignition (LOI) and diatoms. Particle size spectra of the samples 


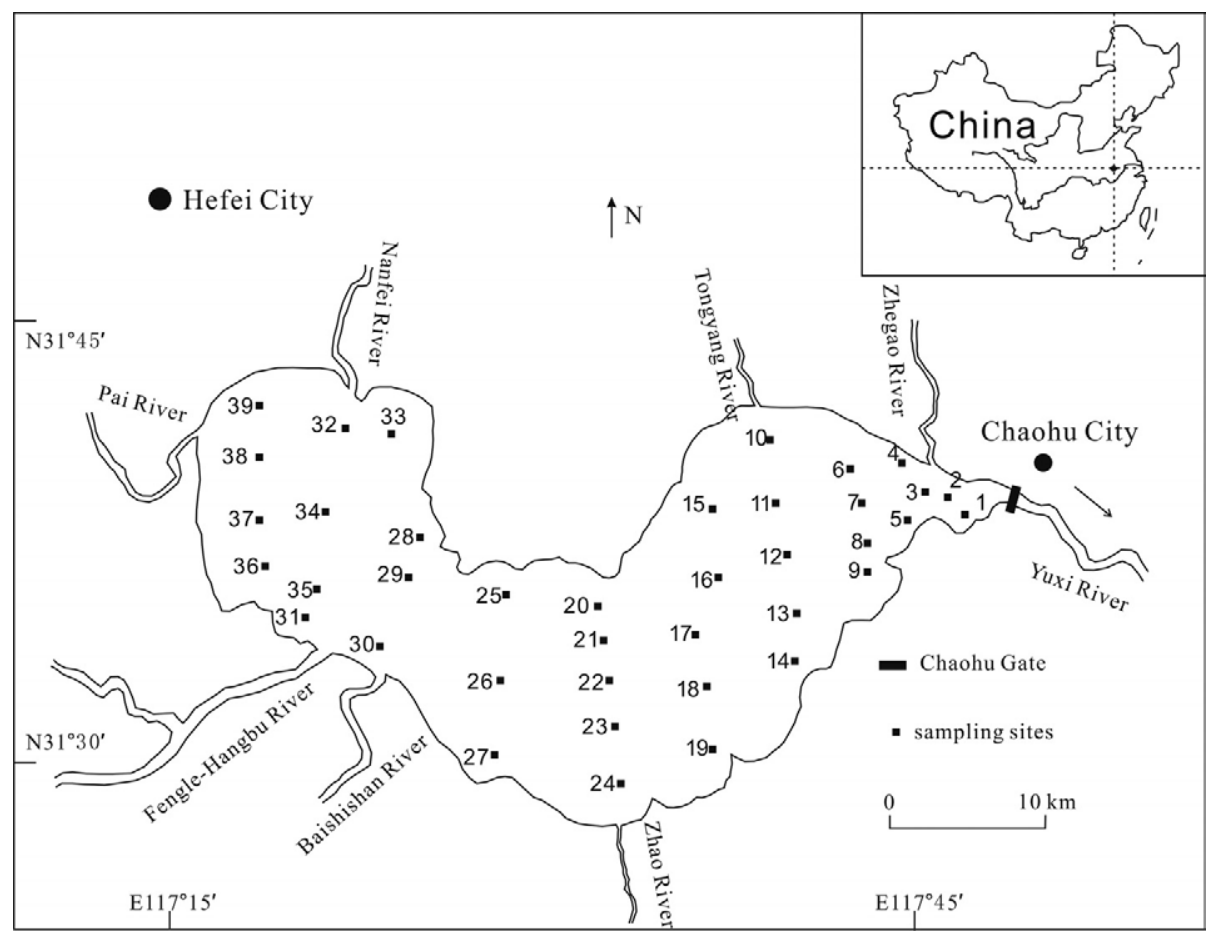

Fig.1. Location and map of Chaohu Lake (southeast China) and the sampling sites.

were determined using a Malvern automated laseroptical particle-size analyzer (Mastersixer-2000). Magnetic susceptibility was measured using a Bartington Instruments MS2 sensor. LOI of samples was measured after $4 \mathrm{~h}$ of exposure at $550^{\circ} \mathrm{C}$ (HEIRI et al. 2001). Diatom samples were treated using hydrogen peroxide and hydrochloric acid in order to remove all organic and carbonate components (BATTARBEE et al. 2001). Microspheres were added to calculate the diatom concentration (BATTARBEE and KNEEN 1982). All samples were mounted on microscope slides using the high refraction mountant Naphrax ${ }^{\circledR}$. Diatoms were identified and counted using an Olympus BX51 microscope with an oil immersion objective at a magnification of $10 \times 100$. Diatom taxonomy mainly followed KRAMMER and LANGE-BerTALOT (1986; 1988; 1991a, b). A minimum of 500 valves were identified and counted for each sample.

\section{Spatial data}

GPS coordinates of 39 sampling sites were recorded in the field. The original coordinate values were $\mathrm{z}$-score transformed and these standard coordinates were used to create the dataset of spatial variables derived from PCNM using the program Spacemaker2 (BORCARD and LEGENDRE 2004). A matrix of Euclidean distances between samples was computed and subsequently truncated based on truncation distance, which was equal to or larger than the largest distance between neighbours. And then, a principal coordinate analysis (PCoA) was performed on the truncated distance matrix. Thereafter, eigenvectors associated with positive eigenvalues were kept and used in the subsequent ordination analysis. 


\section{Data analysis}

All statistical analyses of diatom assemblages were based on percent abundances and included diatom taxa with $\geq 1 \%$ abundance in at least one sample. Diatom distribution data were represented in contour plots, performed using interpolation by a kriging approach with Surfer software (Golden software Inc.). And the percentage data of diatom were square root transformed prior to ordination analyses. Detrended correspondence analysis (DCA) was applied to the diatom percentage data to explore the patterns of species changes and biological species turnover (the gradient length) (JONGMAN et al. 1995). Redundancy analysis or canonical correspondence analysis was selected based on gradient length to explore the relationships between diatom assemblages and explanatory variables (JONGMAN et al. 1995). To reduce the possible effects of the difference in the number of variables included in each set of explanatory variables, we used only those variables that were significant based on a forward selection ( $\mathrm{p}<0.05 ; \mathrm{n}=499$ unrestricted permutations).

The significant variables were then classified into spatial category $[\mathrm{S}]$ and environmental category [E]. Three steps were required to partition variance in diatoms between spatial and environmental categories. First, an RDA with no covariables was used to measure the total amount of variance (as sum of canonical eigenvalues) in the diatom assemblages attributable to all explanatory variables $[\mathrm{S}+\mathrm{E}]$ and the total unexplained variance $\left(100_{-}\right.$ $[\mathrm{S}+\mathrm{E}])$. Second, a partial RDA was used to calculate variance explained by the unique effects of each category ([S] or [E]). In this step, ordination of one explanatory category was run with the other category as covariable. Third, the interaction term [SE] was calculated by subtracting appropriate terms generated during steps 1 and 2 (i.e., $[\mathrm{SE}]=[\mathrm{S}+\mathrm{E}]-[\mathrm{S}]-$ [E]). Variance partitioning analysis is based on standard ordination methods (BORCARD et al. 1992). The ordination was performed using the program CANOCO version 4.5 (TER BRAAK and ŠMILAUER 2002).

\section{Results}

\section{Distribution of surface sediment diatoms}

A total of 24 genera and 68 species were identified in the 39 surface sediment samples. Diatom assemblages were characterized by planktonic diatoms such as Cyclostephanos dubius (Hustedt) Round, Aulacoseira granulata (Ehrenberg) Simonsen and Aulacoseira alpigena (Grunow) Krammer with few epiphytic or benthic species. And smaller abundances of Cyclotella meneghiniana Kützing, Nitzschia palea (Kützing) W. Smith, Tryblionella levidensis W.Smith, Gyrosigma acuminatum (Kützing) Rabenhorst and Stephanodiscus sp. were observed in the samples. The total percentage of all three dominant species together (i.e., C. dubius, A. granulata and A. alpigena) was above $81 \%$ in each sample.

The western part of the lake was dominated by $C$. dubius (Fig. 2). In the central region of the lake, A. granulata was more abundant than the other species. A. alpigena, N. palea and Stephanodiscus sp. were mainly found in the western and eastern basins. G. acuminatum was concentrated in the eastern region. T. levidensis and C. meneghiniana were widely distributed in the lake but with small higher abundance patches in different regions.

\section{Environmental and spatial factors}

The environmental and spatial characteristics in the sampling sites are presented in figure 3 . The percentage frequency dependent susceptibility $\left(\chi_{\mathrm{fd}} \%\right)$ showed minor differences 

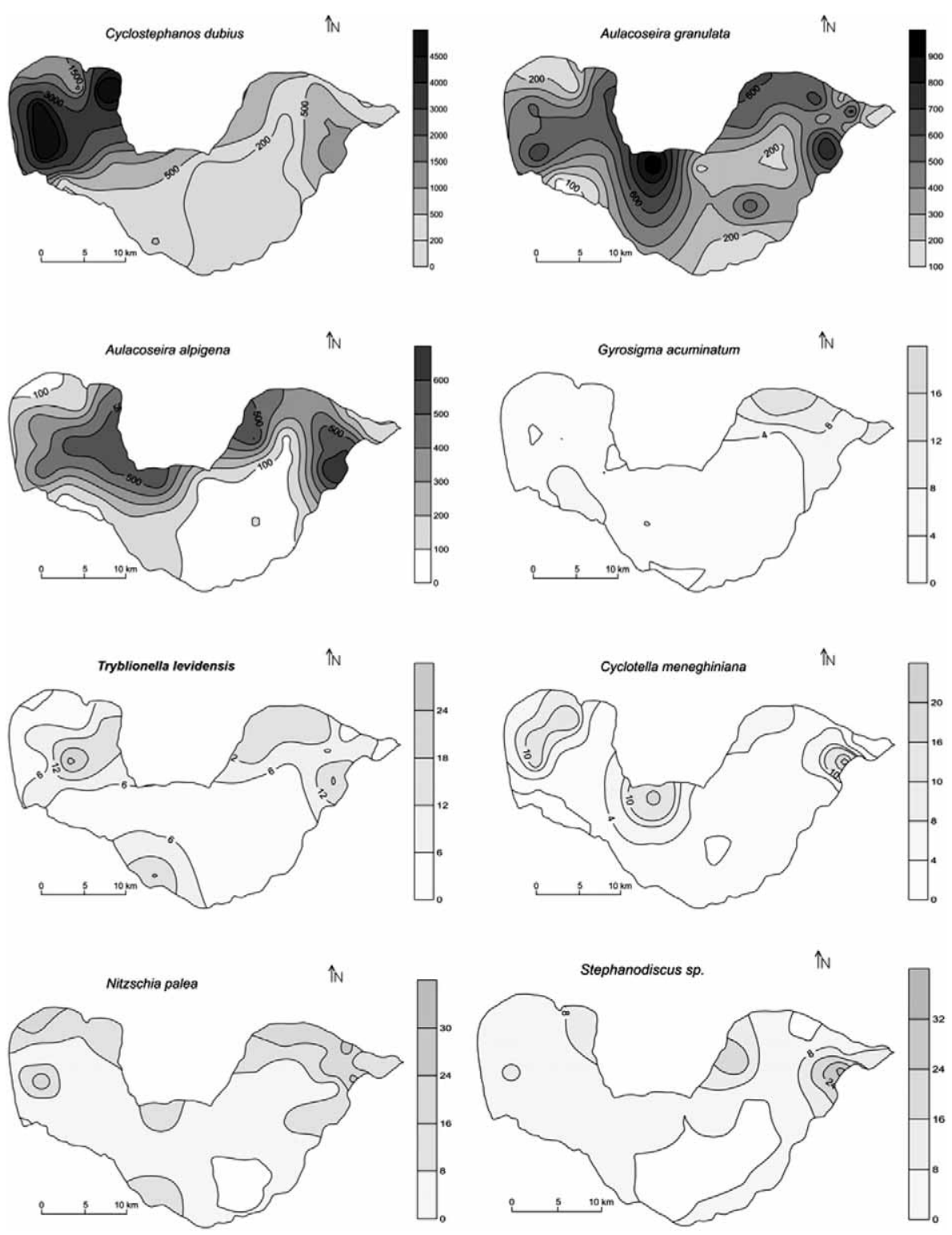

Fig. 2. Spatial distribution of surface sediment diatoms concentrations $\left(10^{4}\right.$ valves dry weight $\left.\mathrm{g}^{-1}\right)$ in Chaohu Lake.

across the lake. Unlike $\chi_{\mathrm{fd}}$, both LOI and particle size showed visible spatial variations. The values of LOI in the western basin were much higher than those in other basins. Sediments in the central basin were characterized by coarse particles. Spatial variables PCNM1 and PCNM2 were calculated and both of them were included in the later analysis. PCNM1 decreased from the eastern basin to the western basin. High values of PCNM2 occurred in the central basin. 


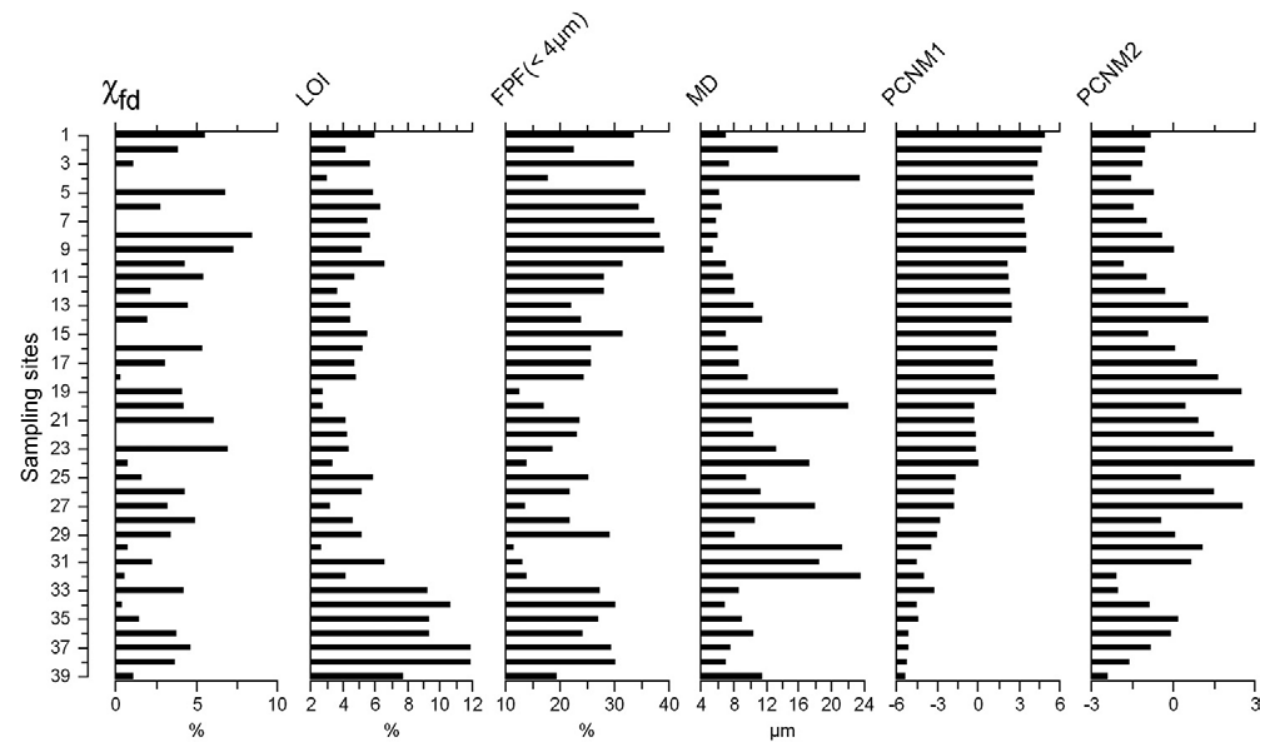

Fig. 3. Variations of environmental and spatial variables in the sampling sites. $\chi_{\mathrm{fd}}-$ the percentage frequency dependent susceptibility, LOI - loss on ignition, FPF - fine particle fraction, MD median grain size, PCNM - principal coordinates of neighbour matrices.

\section{Ordination analyses}

The results showed that the gradient length of DCA axis 1 was 1.04 standard deviations, indicating that redundancy analysis (RDA) was suitable for exploring the relationships between diatom assemblages and spatial and environmental factors (JONGMAN et al. 1995). The environmental variables included $\chi_{\mathrm{fd}}$, LOI, fine particle fraction (FPF) and median grain size (MD). Forward selection identified LOI, FPF and spatial variables (i.e. PCNM1 and PCNM2) as significant environmental variables for the later ordination analysis (Fig. 4). RDA captured the variance in the species-environment and space relationship quite well; $77.2 \%$ by the first two axes (Tab.1). The first ordination axis was positively related to LOI ( $\mathrm{r}=0.703)$, while it was negatively related to PCNM1 $(\mathrm{r}=-0.766)$ and PCNM2 $(\mathrm{r}=$ $-0.197)$. The second ordination axis was negatively related to FPF ( $\mathrm{r}=-0.581)$ and PCNM1 $(\mathrm{r}=-0.260)$ (Tab.1). In the RDA biplot (Fig. 4), most of the samples in the eastern and central region were present in the ordination space characterized by high values of PCNM1 and PCNM2. Samples in the western region of the lake were present in the space characterized by high values of LOI. Some of the samples in the central part of the lake were present in the space characterized by low values of FPF.

\section{Variation partitioning}

Spatial and environmental variables together were able to account for $30 \%$ of the variance in diatom data. Pure environmental variance [E] (non-spatially structured environmental factors) accounted for $12.4 \%$, pure spatial variance [S] for $11.2 \%$, and $6.4 \%$ was atributed to the spatially structured components of the environmental variables [SE] included in the analysis. Seventy per cent of the variance in diatom data was unexplained by either the spatial or environmental variables considered in the analysis. 
Tab.1. Summary statistics for the redundancy analysis of diatom-environment and space. Only environmental variables selected in the forward selection procedure are presented in the ordination.

\begin{tabular}{lcccc}
\hline Axes & 1 & 2 & 3 & 4 \\
\hline $\begin{array}{l}\text { Eigenvalue } \\
\text { Species-environment and space correlations }\end{array}$ & 0.137 & 0.095 & 0.049 & 0.019 \\
$\begin{array}{l}\text { Cumulative percentage variance } \\
\quad \text { of species data }\end{array}$ & 13.7 & 23.1 & 28.1 & 30.0 \\
$\quad$ of species-environment and space relation & 45.6 & 77.2 & 93.6 & 100.0 \\
Correlation with species axes & & & & \\
$\quad$ LOI & 0.703 & -0.051 & -0.211 & -0.313 \\
FPF & 0.071 & -0.581 & -0.374 & -0.180 \\
PCNM1 & -0.766 & -0.260 & -0.163 & -0.128 \\
PCNM2 & -0.197 & -0.077 & 0.632 & -0.019 \\
\hline
\end{tabular}

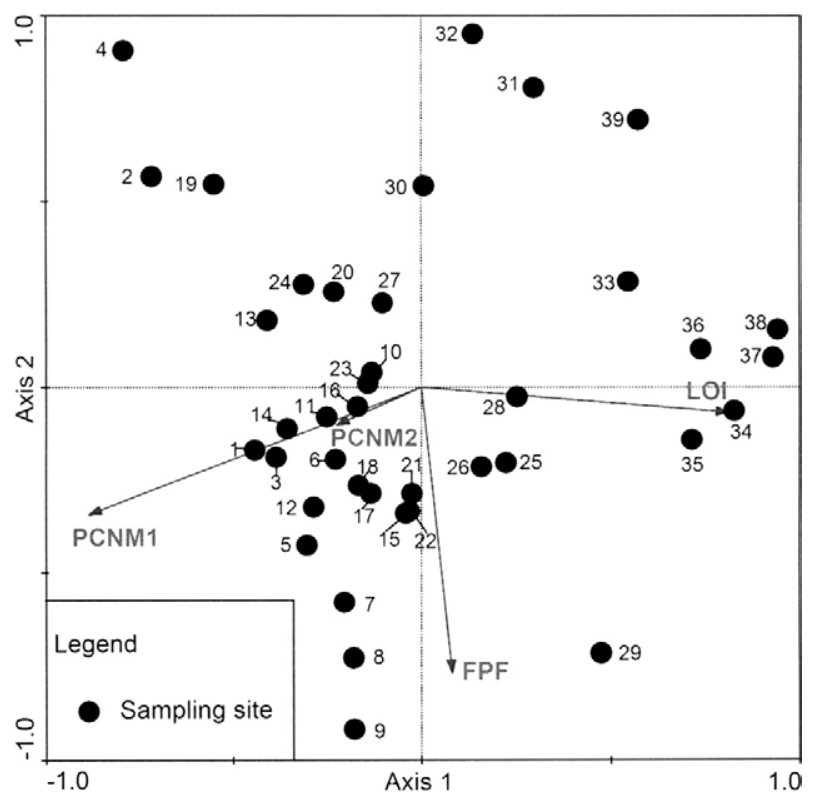

Fig. 4. Redundancy analysis ordination plot (axes 1 and 2). The arrows represent the significant explanatory variables explaining variation in the diatom assemblage.

\section{Discussion}

\section{Environmental factors and diatom distribution}

The diatom assemblages were dominated by three planktonic species (i.e., C. dubius, A. granulata and A. alpigena) in Chaohu Lake. The dominant species varied according to different parts in the lake. For example, the percentage of $C$. dubius was steadily above $60 \%$ in the samples of the western region. However, the diatom assemblages in the central region 
were characterized by Aulacoseira granulata whose abundance was above $50 \%$ in each sample. Compared with the two dominant species, A. alpigena was less abundant in each sample. And A. alpigena was mainly found in the western and eastern basins. The total of percentages of other species was less than $20 \%$ in each sample.

LOI has been widely used as a method to estimate the amount of organic matter in sediments, and it can be used as a proxy for paleoproductivity (SANTISTEBAN et al. 2004). And in the Yangtze floodplain lakes, LOI can be indirectly indicative of lake trophic level (YAO and XUE 2009). RDA indicated that there was a significantly positive correlation between LOI and RDA axis 1 ( $\mathrm{r}=0.703)$, suggesting the influence of trophic level on the diatom assemblages. Cyclostephanos dubius is a typical eutrophic diatom in many shallow nutrient-rich lakes all over the world (BRADSHAW and ANDERSON 2003). Higher nutrient concentrations (e.g, total nitrogen and total phosphorus) were observed in the western part of the lake due to the great amount of industrial and domestic sewage from Hefei City (XU et al. 2003, XIE 2009). Therefore, the aggregation of $C$. dubius in the western region was in response to the high nutrient level in this area. In addition, the western region was also one aggregated area of other species (e.g., A. alpigena, T. levidensis, N. palea and Cyclotella meneghiniana). These species were adapted to the mesotrophic or eutrophic status in the Yangtze floodplain lakes (YANG et al. 2008).

Fine particle fraction was another significant factor influencing diatom distribution. Particle size fraction can provide information on hydrodynamic intensity in the Yangtze floodplain lakes (CHEN et al. 2011, LIU et al. 2012). Coarser grains may indicate strong currents that are able to transport fine particles away; in contrast, finer grains may be indicative of weak hydrodynamic intensity. FPF strongly correlated to axis 2 ( $r=-0.581$ ), suggesting the effect of hydrodynamic intensity on diatom distribution. For instance, the growth of A. granulata was sensitive to flow condition due to its fast sinking rate (HoTzEL and CRoome 1996). The strong hydrodynamic condition in the central basin, suggested by the coarser grains, would favor the development of $A$. granulata.

\section{The influence of spatial variables}

Spatial structures observed in ecological communities can arise from two independent processes: (1) Species' response to environmental factors, which are usually spatially structured; and (2) spatial autocorrelation can also be created directly as a result of contagious biotic processes such as growth, seed dispersal or competition dynamics (ForTIN and DALE 2005, DraY et al. 2006). In most situations, the spatial structure of communities is due to the synchronous effect of these two processes. Variance partitioning analysis (BORCARD et al. 1992) can be used to distinguish the effect of these two sources of spatial structure. In this study, we use partial ordination analysis to untangle the effects of »pure« spatial variance and spatially structured components of the environmental variables. The $11.2 \%$ of total variance in diatom data explained by the sole effect of spatial variables suggests that spatial factors must have a significant effect on diatom distribution in Chaohu Lake. Generally, the first PCNM variables represent coarse patterns, and the last ones represent finer-scale patterns (BORCARD et al. 2004). PCNM1 showed the large-scale spatial gradient from the eastern to the western basin, while PCNM2 exhibited the finer-scale pattern. In addition, some environmental factors showed a visible spatial gradient, such as LOI declining from the western to the eastern basin. It is assumed that the combined effect of 
spatial and environmental variables must exert an influence on diatom distribution. The result indicated that $36.4 \%(=6.4 /(6.4+11.2))$ of the variance in spatial sub-models was due to the interactive effect of spatial and environmental factors.

\section{Further research}

In this study, the combined contribution of environmental and spatial variables to the variance in diatom data was only $30 \%$. The high unexplained contribution may result from inadequate measurement of limnological variables. In shallow lakes, wind-driven resuspension may be responsible for the spatial distribution of diatoms (YANG et al. 2009). In addition, other chemical variables (e.g. TN, TP) of sediment can provide more information on microecological conditions influencing diatom distribution. Therefore, more data about the hydrodynamic condition and chemical factors would improve the conclusions about the spatial distribution of diatoms in Chaohu Lake.

\section{Conclusions}

Surface sediment diatom assemblages were dominated by three planktonic species (i.e. Cyclostephanos dubius, Aulacoseira granulata and A. alpigena) in Chaohu Lake. These three dominant species were unevenly distributed in the lake. The results of ordination analyses indicated that loss on ignition, fine particle fraction, PCNM1 and PCNM2 were four significant factors influencing diatom distribution. It is assumed that the distribution of surface sediment diatoms must be subject to trophic status, hydrodynamic intensity and other spatial variables in the lake. The unique effect of spatial variables (i.e., PCNM1 and PCNM2) captured $11.2 \%$ of the variance in diatom data. Although this value is not very high, the results recommend that spatial variables should be considered in the studies of diatom distribution in large shallow lakes.

\section{Acknowledgements}

We would like to thank Zhang Enlou, Pan Hongxi, Yao Min, Meng Xianghua and Du Chenchang from Nanjing Institute of Geography and Limnology, Chinese Academy of Sciences for their help in the field. This study was supported by the National Natural Science Fund of China (40972217) and by National Basic Research Program of China (2012 CB956100).

\section{References}

Battarbee, R. W., Jones, V. J., Flower, R. J., Cameron, N. G., Bennion, H., Carvalho, L., Juggins, S., 2001: Diatoms. In: Smol, J. P., Birks, H. J. B., Last, W. M. (eds), Tracking environmental change using lake sediments, 3 . Terrestrial, algal, and siliceous indicators, 155-202. Kluwer Academic Publisher, Dordrecht.

Battarbee, R. W., KneEN, M. J., 1982: The use of electronically counted microspheres in absolute diatom analysis. Limnology and Oceanography 27, 184-188. 
Beisner, B. E., Peres-Neto, P. R., Lindström, E. S., Barnett, A., Longhi, M. L., 2006: The role of environmental and spatial processes in structuring lake communities from bacteria to fish. Ecology 87, 2985-2991.

Borcard, D., Legendre, P., Drapeau, P., 1992: Partialling out the spatial component of ecological variation. Ecology 73, 1045-1055.

BORCARD, D., LEGENDRE, P., 2002: All-scale spatial analysis of ecological data by means of principal coordinates of neighbour matrices. Ecological Modelling 153, 51-68.

BorCARD, D., LEGEndRe, P., 2004: SpaceMaker2 - User's guide. Département de sciences biologiques, Université de Montréal.

Borcard, D., Legendre, P., Avois-Javquet, C., Tuomisto, H., 2004: Dissecting the spatial structure of ecological data at multiple scales. Ecology 85, 1826-1832.

Bradshaw, E. G., ANDERSON, N. J., 2003: Environmental factors that control the abundance of Cyclostephanos dubius (Bacillariophyceae) in Danish lakes, from seasonal to century scale. European Journal of Phycology 38, 265-276.

Brind'Amour, A., Boisclair, D., Legendre, P., Borcard, D., 2005: Multiscale spatial distribution of a littoral fish community in relation to environmental variables. Limnology and Oceanography 50, 465-479.

Cao, Y. M., Zhang, E. L., Chen, X., Anderson, N. J., Shen, J., 2012: Spatial distribution of sub-fossil Chironomidae in surface sediments of a large, shallow and hypertrophic lake (Taihu, SE China). Hydrobiologia 691, 59-70.

Chen, X., YAng, X. D., Dong, X. H., LiU, Q., 2011: Nutrient dynamics linked to hydrological condition and anthropogenic nutrient loading in Chaohu Lake (southeast China). Hydrobiologia 661, 223-234.

Cózar, A., Bruno, M., Bergamino, N., Úbeda, B., Bracchini, L., Dattilo, A. M., LoisELLE, S. A., 2012: Basin-scale control on the phytoplankton biomass in Lake Victoria, Africa. Plos One 7, e29962.

Dray, S., Legendre, P., Peres-Neto, P. R., 2006: Spatial modelling: a comprehensive framework for principal coordinate analysis of neighbour matrices (PCNM). Ecological Modelling 196, 483-493.

Fortin, M. J., DAle, M. B., 2005: Spatial analysis: a guide for ecologists. Cambridge University Press, Cambridge.

HeIRI, O., LotTer, A. F., LemCKe, G., 2001: Loss on ignition as a method for estimating organic and carbonate content in sediments: reproducibility and comparability of results. Journal of Paleolimnology 25, 101-110.

Hotzel, G., CRoOme, R., 1996: Population dynamics of Aulacoseira granulata (EHR) SimOnSEN (Bacillariophyceae, centrales), the dominant alga in the Murray River, Australia. Archiv für Hydrobiologie 136, 191-215.

Jongman, R. H. G., Ter BraAk, C. J. F., VAn Tongeren, O. F. R., 1995: Data analysis in community and landscape ecology. Cambridge University Press, Cambridge.

Krammer, K., LANGe-Bertalot, H., 1986: Bacillariophyceae, 1: Naviculaceae. In: EtTL, H., Gerloff, J., Heynig, H., Mollenhauer, D. (eds), Süsswasserflora von Mitteleuropa 2/1. Gustav Fischer Verlag, Jena. 
Krammer, K., LANGe-Bertalot, H., 1988: Bacillariophyceae, 2: Bacillariaceae, Epithemiaceae, Surirellaceae. In: Ettl, H., Gerloff, J., Heynig, H., Mollenhauer, D. (eds), Süsswasserflora von Mitteleuropa 2/2. Gustav Fischer Verlag, Jena.

Krammer, K., Lange-Bertalot, H., 1991a: Bacillariophyceae, 3: Centrales, Fragilariaceae, Eunotiaceae. In: Ettl, H., Gerloff, J., Heynig, H., Mollenhauer, D. (eds), Süsswasserflora von Mitteleuropa 2/3. Gustav Fischer Verlag, Jena.

Krammer, K., Lange-Bertalot, H., 1991b: Bacillariophyceae, 4: Achnanthaceae, Kritische Ergänzungen zu Navicula (Lineolate) und Gomphonema. In: ETTL, H., GERLOFF, J., HeYnig, H., Mollenhauer, D. (eds), Süsswasserflora von Mitteleuropa 2/4. Gustav Fischer Verlag, Jena.

LEGENDRE, P., Fortin, M. J., 1989: Spatial pattern and ecological analysis. Plant Ecology 80, 107-138.

LiU, Q., YAng, X. D., Anderson, N. J., LiU, E. F., Dong, X. H., 2012: Diatom ecological response to altered hydrological forcing of a shallow lake on the Yangtze floodplain, SE China. Ecohydrology DOI: 10.1002/eco.222

Nöges, P., Kangur, K., Nöges, T., Reinart, A., Simola, H., Viljanen, M., 2008: Highlights of large lake research and management in Europe. Hydrobiologia 599, 259-276.

Santisteban, J. I., Mediavilla, R., LóPez-PAmo, E., Dabrio, C. J., Zapata, M. B. R., Carcía, M. J. G., Castaño, S., Martínez-Alfaro, P. E., 2004: Loss on ignition: a quantitative method for organic matter and carbonate mineral content in sediments? Journal of Paleolimnology 32, 287-299.

Shang, G. P., ShAng, J. C., 2005: Causes and control countermeasures of eutrophication in Chaohu Lake, China. Chinese Geographical Science 15, 348-354.

Sharma, S., Legendre, P., De CÁCERES, M., Boisclair, D., 2011: The role of environmental and spatial processes in structuring native and non-native fish communities across thousands of lakes. Ecography 34, 762-771.

Smol, J. P., Cumming, B. F., 2000: Tracking long-term changes in climate using algal indicators in lake sediments. Journal of Phycology 36, 986-1011.

Sweetman, J. N., RÜHLAnd, K. M., Smol, J. P., 2010: Environmental and spatial factors influencing the distribution of cladocerans in lakes across the central Canadian Arctic treeline region. Journal of Limnology 69, 76-87.

Ter BraAK, C. J. F., ŠMilauer, P., 2002: CANOCO Reference Manual and CanoDraw for Windows User's Guide: Software for Canonical Community Ordination (Version 4.5). Microcomputer Power, Ithaca.

Wang, S., Dou, H. (eds), 1998: Memoirs of lakes in China. Science Press, Beijing.

XIE, P., 2009: Reading about the histories of cyanobacteria, eutrophication and geological evolution in Lake Chaohu (in Chinese). Science Press, Beijing.

Xu, F. L., TAo, S., Dawson, R. W., Xu, Z. R., 2003. The distributions and effects of nutrients in the sediments of a shallow eutrophic Chinese lake. Hydrobiologia 429, 85-93.

Yao, S., Xue, B., 2009: Recent environmental evolution of Shijiuhu Lake inferred from lake sediments (in Chinese). Quaternary Research 29, 248-255.

Yang, X. D., Anderson, N. J., Dong, X. H., Shen, J., 2008: Surface sediment diatom assemblages and epilimnetic total phosphorus in large, shallow lakes of the Yangtze 
Chen X., Yang X., Dong X., Liu E.

floodplain: their relationships and implications for assessing long-term eutrophication. Freshwater Biology 53, 1273-1290.

Yang, H., Flower, R. J., Battarbee, R. W., 2009. Influence of environmental and spatial variables on the distribution of surface sediment diatoms in an upland loch, Scotland. Acta Botanica Croatica 68, 367-380. 